\title{
Cortes histológicos dos órgãos vegetativos do girassol (Helianthus annuus L., Asteraceae): uma contribuição para o ensino da botânica
}

\section{Histological sections of the sunflower vegetative organs (Helianthus annuus L., Asteraceae): a contribution to the teaching of botany}

\author{
Maria Isabel Gomes dos SANTOS ${ }^{(1)}$; Thaynnara Paula dos Santos LIRA ${ }^{(2)}$; Luiz Eduardo \\ Bezerra SILVA ${ }^{(3)}$; Rafael Lima Vieira SANTOS ${ }^{(4)}$; Israel Paulo da Silva JUNIOR ${ }^{(5)}$; Dacio \\ Rocha BRITO ${ }^{(6)}$.
}

(1) Universidade Estadual de Alagoas - UNEAL, Graduanda em Ciências Biológicas, E-mail: isabelsantos4273@email.com

(2) Universidade Estadual de Alagoas - UNEAL, Graduada em Ciências Biológicas, E-mail: thaynnaralira12@gmail.com

(3) Universidad de Costa Rica - UCR, Mestrando em Biologia, E-mail: luiz.e.b.leit@gmail.com

(4) Universidade Estadual de Alagoas - UNEAL, Graduando em Ciências Biológicas, E-mail: rafaell8006@gmail.com

(5) Universidade Estadual de Alagoas - UNEAL, Graduando em Ciências Biológicas, E-mail: israelpaulojr94@gmail.com

(6) Universidade Estadual de Alagoas - UNEAL, Docente do Curso de Ciências Biológicas, E-mail: dacio@uneal.edu.br

Resumo - A anatomia vegetal estuda as células e os tecidos vegetais, assim como a estrutura interna dos organismos vegetais. Buscando contribuir com o ensino, estudou-se as estruturas anatômicas do girassol (H. annuus L.), utilizando técnicas simples e de fácil replicação. Sendo assim, fizeram-se cortes histológicos testando diferentes cortes histológicos a mão livre na raiz, caule, pecíolo, folha e inflorescência do girassol. Os cortes foram feitos e preparados no laboratório multidisciplinar do campus I da Uneal, Arapiraca - AL, utilizou-se microscópio óptico com lentes de aumento de 10x e 20x vezes para as observações. Para a identificação das estruturas, utilizou-se os livros: Anatomia e Morfologia Vegetal (FERRI, 1981); Sistemática Vegetal (THAMES, 1977); e, Biologia Vegetal (RAVEN, 2014), além de artigos científicos do Google acadêmico para comparação de literaturas. Verificou-se que a técnica de preparo dos cortes é eficaz para a visualização das estruturas anatômicas internas do girassol (H. annuus L.) ao microscópio óptico. Foi possível observar células e tecidos importantes que são estudados nas aulas de botânica, sendo os cortes transversais os melhores para visualização e identificação dos tecidos.Concluiu-se que as técnicas utilizadas são simples, de fácil execução e podem contribuir para produção de materiais, tanto no ensino básico como no superior e para estudos mais abrangentes.

Palavras-chave: Asteracea. Biologia vegetal. Prática de Ensino.

Abstract - The plant anatomy studies plant cells and plant tissues, as well as the internal structure of plant organisms. Seeking to contribute to teaching, the anatomical structures of the sunflower (H. annuus L.) were studied, using simple and easy replication techniques. Therefore, 


\section{Revista Ambientale \\ Revista da Universidade Estadual de Alagoas/UNEAL \\ e-ISSN 2318-454X, Ano 13, Vol. 13 (1), 2021}

histological cuts were made by testing different freehand histological cuts on the root, stem, petiole, leaf and inflorescence of the sunflower. The cuts were made and prepared in the multidisciplinary laboratory on campus I at Uneal, Arapiraca - AL, an optical microscope with 10x and 20x magnification lenses was used for the observations. For the identification of structures, the following books were used: Vegetal Anatomy and Morphology (FERRI, 1981); Vegetal Systematics (THAMES, 1977); and, Vegetal Biology (RAVEN, 2014), in addition to academic Google scientific articles for comparing literature. It was found that the cut preparation technique is effective for visualizing the internal anatomical structures of the sunflower (H. annuus L.) under an optical microscope. It was possible to observe important cells and tissues that are studied in botany classes, with cross sections being the best for visualization and identification of tissues. It was concluded that the techniques used are simple, easy to perform and can contribute to the production of materials, both in basic as well as higher education and for more comprehensive studies.

Keywords: Asteraceae. Plant Biology. Teaching Practice.

\section{Introdução}

O girassol (H. annuus L.), é uma dicotiledônea anual, que pertence a ordem Asterales e família Asteraceae. O gênero deriva do grego hélios, que significa sol, e de anthus, que significa flor, ou "flor do sol", que gira seguindo o movimento do sol sendo este um gênero complexo, compreendendo 49 espécies e 19 subespécies, sendo 12 espécies anuais e 37 perenes (CAVASIN JUNIOR, 2001, p. 13).

O girassol é uma planta de origem Norte Americana. Esta cultura apresenta grande importância na economia mundial, despontando como uma grande fonte de energia alternativa (biodiesel), sendo cultivada em todos os continentes em uma área de aproximadamente 18 milhões de hectares, apresentando-se como a quarta oleaginosa em produção de grãos e a quinta em área cultivada (SILVEIRA et al., 2009, p. 01).

Apesar da família Asteraceae ser uma importante componente dos sistemas agriculturais, pouca atenção tem sido dada para a biologia dessa família, e alguns aspectos ainda necessitam ser estudados (GROMBONE-GUARATINI et al., 2004, p. 05). Sendo necessários estudos aprofundados, principalmente da anatomia vegetal, afim de haver uma melhor compreenção do desempenho dos indivíduos que compõem esta família.

Existem alguns tipos de estudos relacionados a estrutura interna destes seres vivos, os vegetais, como a anatomia descritiva, anatomia ontogenética, anatomia fisiológica. Independente do tipo de estudo que se pretende, faz-se necessário a preparação de lâminas histológicas que possibilitem a observação dos diversos tecidos que formam a estrutura da planta (APPEZZATO-DA-GLÓRIA; CARMELLO-GUERREIRO, 2006, p. 247). Sendo assim, objetivou-se realizar cortes histológicos dos órgãos vegetativos do girassol (H. annuus L.) para analisar estruturas anatômicas com técnica simples e de fácil replicação.

\section{Procedimento metodológico}


Revista Ambientale

Revista da Universidade Estadual de Alagoas/UNEAL

e-ISSN 2318-454X, Ano 13, Vol. 13 (1), 2021

O experimento foi realizado no laboratório multidisciplinar do Curso de Ciências Biológicas, Campus I, Arapiraca, da Universidade Estadual de Alagoas, localizada na Rua Governador Luís Cavalcante, s/n - Alto do Cruzeiro, Arapiraca - AL, 57312-000, latitude $9^{\circ} 44^{\prime} 54.0^{\prime \prime} \mathrm{S}$, longitude $36^{\circ} 39^{\prime} 13.8^{\prime \prime} \mathrm{W}$.

Utilizou-se para os cortes e preparação das lâminas de observação ao microscópio, lâminas de aço para barbear, lâminas de vidro, lamínulas, placas de isopor de $10 \mathrm{~mm}$, esmalte incolor para selagem das lamínulas, placas de Petri, hipoclorito, água destilada, corante vegetal (azul de metileno), microscópio óptico, espátulas, lápis para anotações nas lâminas e laminário.

Os microscópios ópticos utilizados foram os comumente encontrados nas escolas do ensino básico. As lentes de aumento usadas foram de 10x e 20x vezes. Após a visualização foram efetuados registros fotográficos e nas lâminas selecionadas colocou-se lamínulas e esmalte (lutagem) para selagem. As lâminas prontas e identificadas foram colocadas em laminário para uso técnico-científico .

Para condução do trabalho, inicialmente foi realizado o plantio das sementes de girassol (H. annus L.) em caqueiras, que facilitou o transporte da planta até o laboratório a fim de evitar o ressecamento (Figura 1). Com as plantas desenvolvidas fez-se a coleta do material botânico que é a etapa inicial e uma das mais importantes para o sucesso do estudo anatômico, pois segundo Cortez (2016, p. 29), as regiões de interesse devem ser coletadas de plantas sadias, considerando o órgão a ser estudado e seu estado de desenvolvimento.

Figura 1: a) plantas do girassol (H. annuus L.) já em condições de realizar cortes para observação e b) cultivo das plantas em caqueiras.

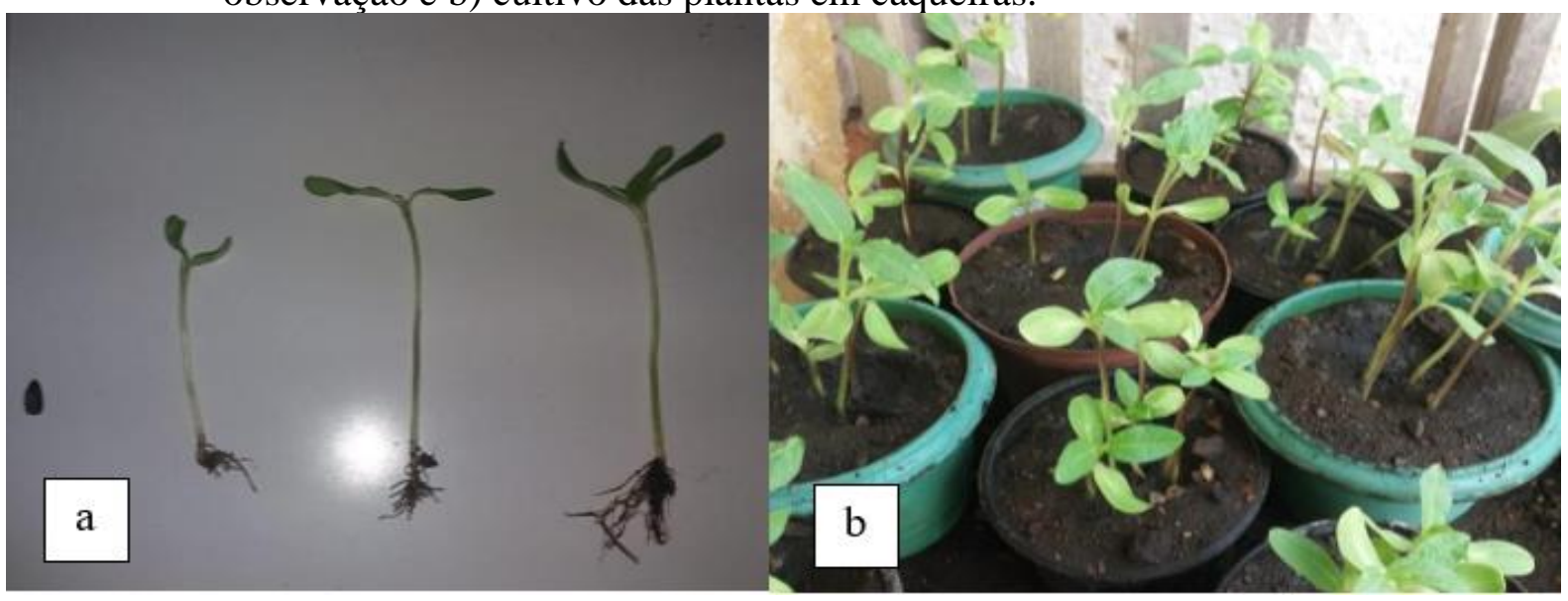

Fonte: SANTOS, 2019.

Para os cortes histológicos à mão livre utilizou-se raiz, caule, pecíolo, folha e inflorescência do girassol (H. annuus L.) (Figura 2), os tipos de cortes foram transversais, longitudinal e paradérmicos. Após obtenção das secções, fez-se observações das estruturas anatômicas internas utilizando microscópio óptico, procurando identificá-las para melhor compreender tais estruturas, procedimento realizado com base no Manual Prático de Morfologia e Anatomia Vegetal de Cortez, Silva e Chaves (2016, p. 29). 
Figura 2: a) Material utilizado para a realização dos cortes no girassol (H. annuus L.).

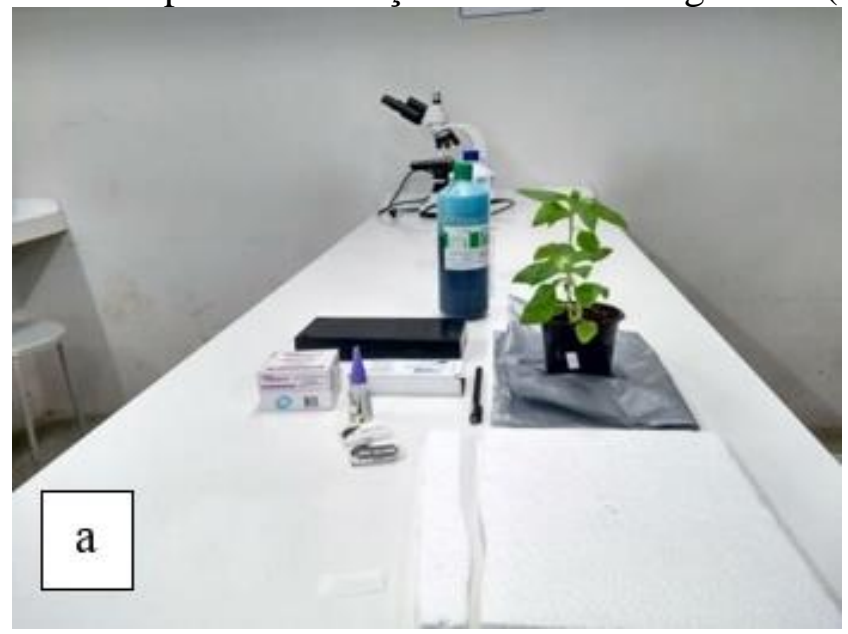

Fonte: SANTOS, 2019.

Após o corte, as secções obtidas dos órgãos das plantas foram, inicialmente, colocadas em uma placa de Petri, que continha hipoclorito de sódio $(\mathrm{NaClO})$, onde permaneceram por aproximadamente 2 minutos, até ser observado o descoramento, em seguida foram colocados em uma segunda placa de Petri com água destilada para a retirada do excesso do hipoclorito. As secções são necessárias para observação das estruturas anatômicas ao microscópio.

Posteriormente, colocou-se corante azul de metileno para evidenciar os núcleos das células e tecidos vegetais, segundo Santos de Souza (2015, p. 23) é um corante vital, ou seja, não mata a célula, por isso é recomendado para observação de material vivo, também é utilizado para corar mucilagem. Os fragmentos (secções) permaneceram apenas 10 segundos no meio com azul de metileno, para evitar que os cortes ficassem com uma coloração forte o que dificultaria a visualização das estruturas anatômicas dos órgãos estudados. Em seguida as seções retiradas do meio com azul de metileno foram colocadas em placa de Petri contendo água destilada para a remoção do excesso de corante (Figura 3).

Figura 3: Passos de preparação dos fragmentos do girassol (H. annuus L.). a) Placa de Petri contendo Hipoclorito de Sódio, b) Placa de Petri contendo água destilada (H20), c) Placa de Petri contendo o corante vegetal Azul de Metileno, d) Placa de Petri contendo água destilada $(\mathrm{H} 2 \mathrm{O})$. 


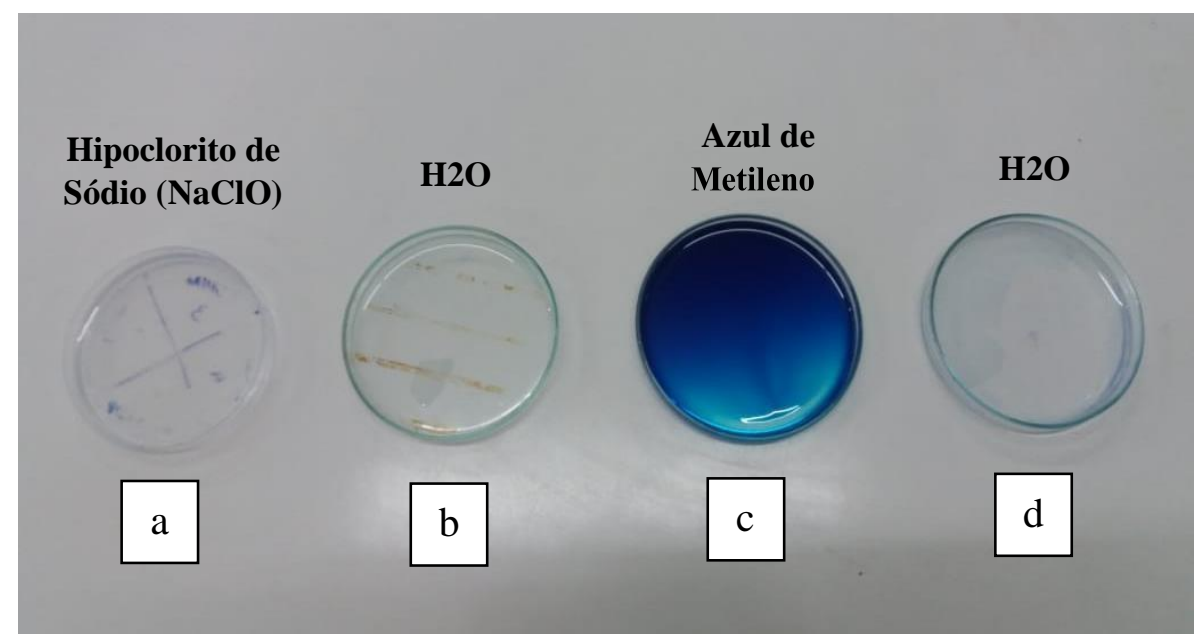

Fonte: SANTOS, 2019.

Para raízes, caules e inflorescências os cortes foram transversais, buscando a observação os tecidos existentes na estrutura interna desses órgãos.

Para as folhas foram feitos cortes paradérmicos, objetivando observar a epiderme abaxial e adaxial a fim de observar os tecidos e em especial os estômatos, fez-se também cortes transversais. Foi selecionando as melhores secções para visualização ao microscópio.

Todos os cortes histológicos dos órgãos vegetais resultaram em camadas finas que foram utlizadas para preparadas lâminas de observação ao microscópio.

Para a identificação das estruturas foram utilizados livros de Anatomia e Morfologia Vegetal (FERRI, 1981), Sistemática Vegetal (THAMES, 1977), Biologia Vegetal (RAVEN, 2014), e artigos científicos para comparação de literaturas.

\section{Resultados e Discussão}

Na Figura 4, verifica-se uma visão geral da planta do girassol.

Figura 4. a) Morfologia externa do girassol (H. annuus L.). b) Detalhe da raiz do girassol.
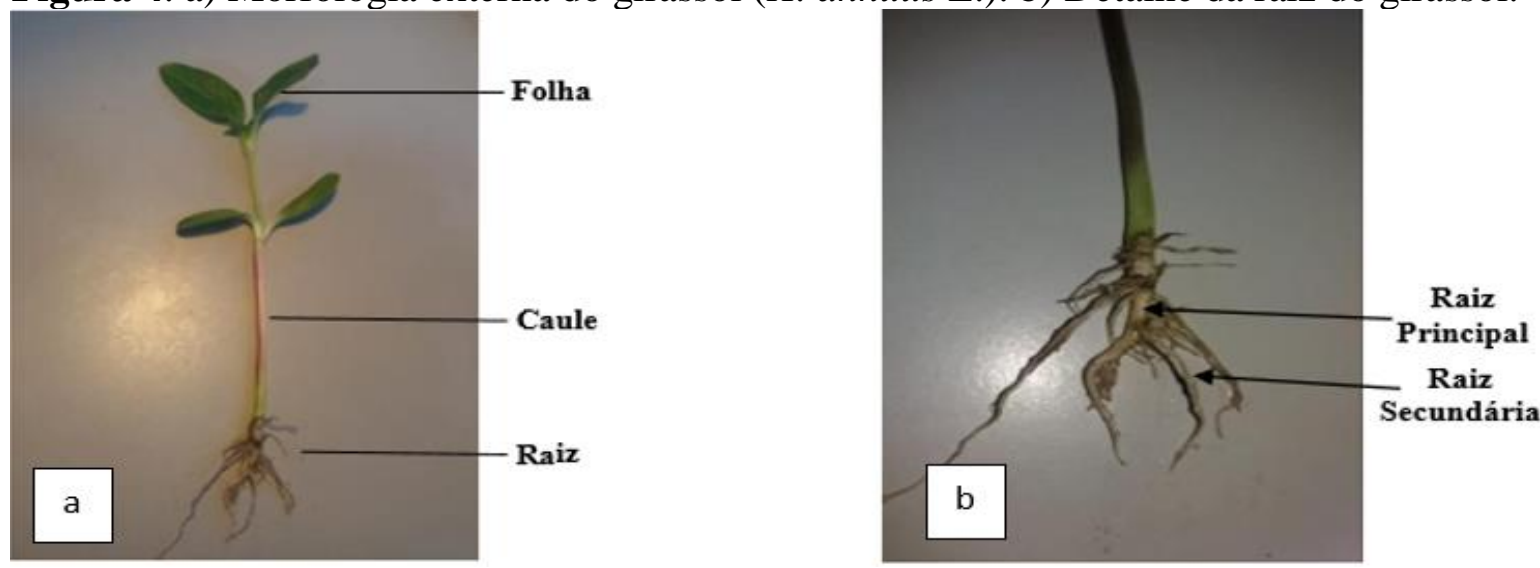

Fonte: SANTOS, 2019. 


\section{Revista Ambientale \\ Revista da Universidade Estadual de Alagoas/UNEAL \\ e-ISSN 2318-454X, Ano 13, Vol. 13 (1), 2021}

Por se tratar de uma planta completa, com raiz, caule e folha, o girassol pode ser utilizado nas aulas de Botânica para ser estudado também quanto a sua morfologia externa e servindo como instrumento de aulas práticas o que pode contribuir com os professores e com os alunos no uso de uma planta conhecida na região e utilizando métodos e técnicas facilmente replicadas nas escolas.

As plantas apresentam o corpo dividido em órgão vegetativos (raiz, caule e folha) e órgãos reprodutivos (flor, fruto e semente), para o entendimento da anatomia vegetal, faz-se necessário imaginar a planta com um corpo único, onde cada tecido está ligado de forma direta ou indireta. À medida que o embrião cresce e se torna uma plântula, o caule e a raiz cada vez mais divergem um do outro em sua organização. A raiz cresce mais ou menos como um órgão cilíndrico ramificado; o caule é composto por nós e entrenós, com folhas e ramos conectados aos nós (EVERT; ESAU, 2013, p. 29).

Verificou-se que a técnica de preparo dos cortes utilizadas no estudo, baseada no Os melhores cortes para visualização das estruturas foram as secções transversais. Na geral foram obtidas secções que permitiram uma clara observação das estruturas internas, tais como: parede celular, epiderme, parênquima paliçádico, parênquima lacunoso, córtex, endoderme, vasos de xilema e floema, além de organelas como núcleo.

Os cortes realizados nas raízes do girassol (H. annuus L.) (Figura 5) foram em raízes primárias, que são as primeiras raízes da planta que se origina ainda no embrião.

Figura 5. Corte transversal da raiz de girassol (H. annuus L.) com corante azul de metileno: vista geral com aumento de 10x. (ME: Medula; EP: Epiderme; C: Córtex; PI: Parênquima Interfascicular).

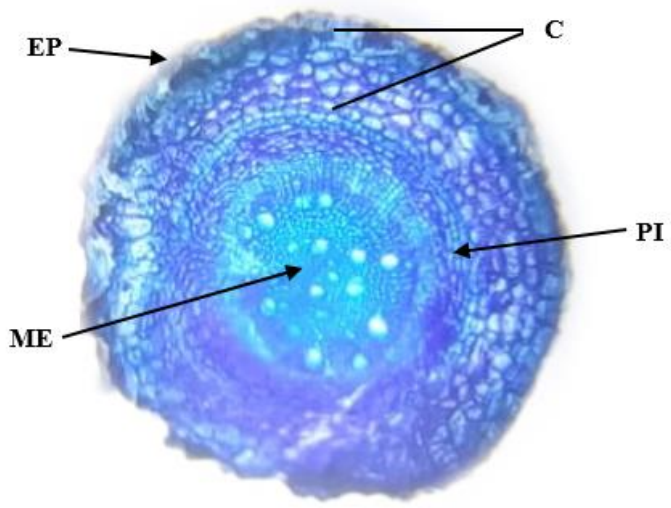

Fonte: SANTOS, 2019.

Segundo USP (2002, p. 02), nas gimnospermas e dicotiledôneas, a raiz primária (axial ou pivotante) cresce em direção ao solo, originando raízes secundárias, também chamadas raízes laterais.

Verificou-se que o córtex ocupa a maior área do corpo primário da maioria das raízes. Nas células do córtex pode ocorrer armazenamento de amido e outras substâncias e comumente não possuem cloroplastos. Essas secções são importantes para uma discussão sobre as estruturas internas encontradas em raízes. Como evidenciar que independente do grau de diferenciação, o tecido cortical possui numerosos espaços intercelulares (espaços cheios de ar, essenciais para a aeração das células). Também pode-se demonstrar que as células corticais possuem numerosos contatos entre si e seus protoplasmas encontram-se ligados por plasmodesmos. Assim, as substâncias que transitam pelo córtex podem atravessar as células, via protoplasma/plasmodesmo ou parede celular (USP, 2002, p. 02). 


\section{Revista Ambientale \\ Revista da Universidade Estadual de Alagoas/UNEAL \\ e-ISSN 2318-454X, Ano 13, Vol. 13 (1), 2021}

A estrutura da raiz de uma dicotiledônea, ainda em crescimento primário, apresenta as zonas anatômicas características da anatomia da raiz, epiderme, zona cortical e cilindro central ou medula, limitado externamente pela endoderme (ROSA, MOREIRA E MONTEIRO, 1985, p. 10), estruturas que foram visualizadas nas secções realizadas no presente trabalho.

Observa-se na Figura 6 o corte realizado no caule do girassol, onde é possível identificar diversos tecidos, inclusive vasos de xilema e de floema cuja disposição pode servir de base de discussão em sala de aula para mostrar, por exemplo, as diferenças entre monocotiledôneas e dicotiledôneas pela organização dos feixes vasculares, podendo ainda estudar que a anatomia da planta pode influenciar na translocação de nutrientes (ROSOLEM; LEITE, 2007, p. 01).

Figura 6. Anatomia do caule da planta do girassol (H. annuus L.). Secção transversal com corante azul de metileno. a) visão geral do caule com aumento de 10x. b) visão ampliada da medula contendo tecido parenquimatosos e dos feixes vasculares com aumento de 20x. (EP: Epiderme; FV: Feixes Vasculares; TR: Tricoma; ME: Medula; FL: Floema; XI: Xilema, CV: Câmbio Vascular).
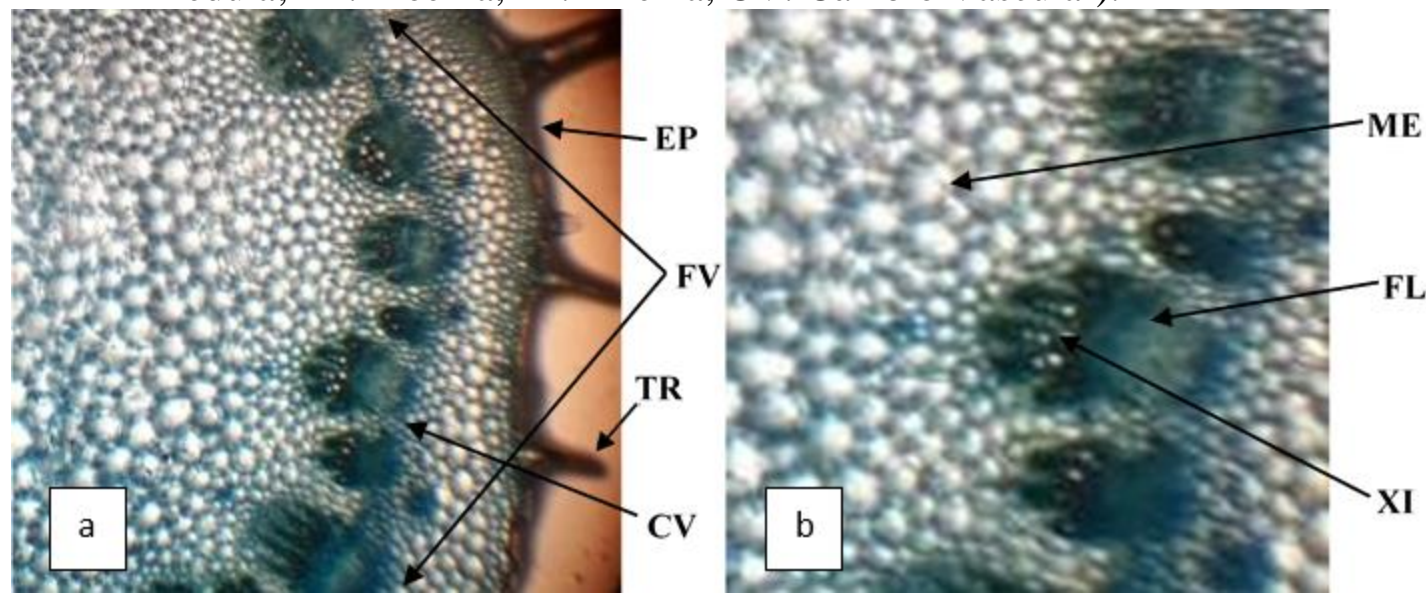

Fonte: SANTOS, 2019.

No caso de verificar as diferenças entre monocotiledôneas e dicotiledôneas, segundo UCB (2006, p. 36), o caule das dicotiledôneas e o caule das monocotiledôneas, diferem-se principalmente por apresentar câmbio fascicular e um só ciclo de feixes, enquanto que nas monocotiledôneas os feixes estão espalhados pelo parênquima. Nos cortes realizados no caule do girassol (H. annuus L.) pode-se perceber bem esta diferenciação, pois os feixes vasculares de xilema e floema do vegetal em uso estavam localizados e organizados perifericamente, formando um ciclo, característica comum entre as dicotiledôneas.

Outras observações importantes podem ser utilizadas no ensino de botânica. Em trabalho semelhante, Castro e Chalco (2006, p. 04) fizeram a explicação do conteúdo sobre os vasos condutores de seiva para que alunos entendessem o funcionamento dessas estruturas. Foi explanado sobre a condução de seiva, na qual o xilema é responsável pelo transporte da água e sais minerais captados pela raiz do vegetal (seiva bruta) e o floema que transporta os nutrientes produzidos nas folhas (seiva elaborada) para toda a planta e através da prática foi explicado como ocorre todo este processo.

Raven (2014) citado por Ribeiro (2017, p. 54) afirma ser o xilema é um tecido vascular complexo, através do qual a maior parte da água e sais minerais são conduzidos no vegetal, caracterizado pela presença de elementos traqueais. Já o floema é o tecido condutor de seiva elaborada das plantas 


\section{Revista Ambientale \\ Revista da Universidade Estadual de Alagoas/UNEAL \\ e-ISSN 2318-454X, Ano 13, Vol. 13 (1), 2021}

vasculares, o qual é composto por elementos crivados, vários tipos de células de parênquima, fibras e esclereídes. Appezzato e Carmelo (2006) alegam que, no corpo vegetal, os vários sistemas de tecido distribuem-se, segundo padrões característicos, de acordo com o órgão considerado, o grupo vegetal, ou ambos. Basicamente, os padrões se assemelham no seguinte: o sistema vascular é envolvido pelo sistema fundamental e o sistema dérmico reveste a planta. As principais variações de padrão dependem da distribuição relativa do sistema vascular no sistema fundamental. As afirmações aqui explicitadas são relevantes para citação em sala de aula, dependendo do nível de conhecimento da turma.

$\mathrm{Na}$ Figura 7, observa-se cortes transversais em folha do girassol. Percebe-se que o parênquima paliçadico, formado por células uniformes e alongadas e dispostas perpendicularmente, é formado por 4 camadas de células e o parênquima lacunoso compõe um grupo de células dispersas no mesófilo. Esse parênquima encontra-se, geralmente, localizado logo abaixo de superfície adaxial (epiderme superior), e trata-se de um tecido fotossintetizante. Isso pelo fato de essas células possuírem cloroplastos, e nessa posição, adaxial, os raios solares atingem a folha com maior intensidade, porém, pode ser encontrado, também, na face abaxial (Instituto de Biologia, 2007, p. 01).

Figura 7. Corte transversal da folha de girassol (H. annuus L., Asteraceae): vista geral. a) visão geral da folha com aumento de 10x. b) visão ampliada com aumento de 20x. (ES: Epiderme Superior (adaxial); EI: Epiderme Inferior (abaxial); C: Cutícula; PP: Parênquima Paliçádico; FV: Feixes Vascular; PL: Parênquima Lacunoso).
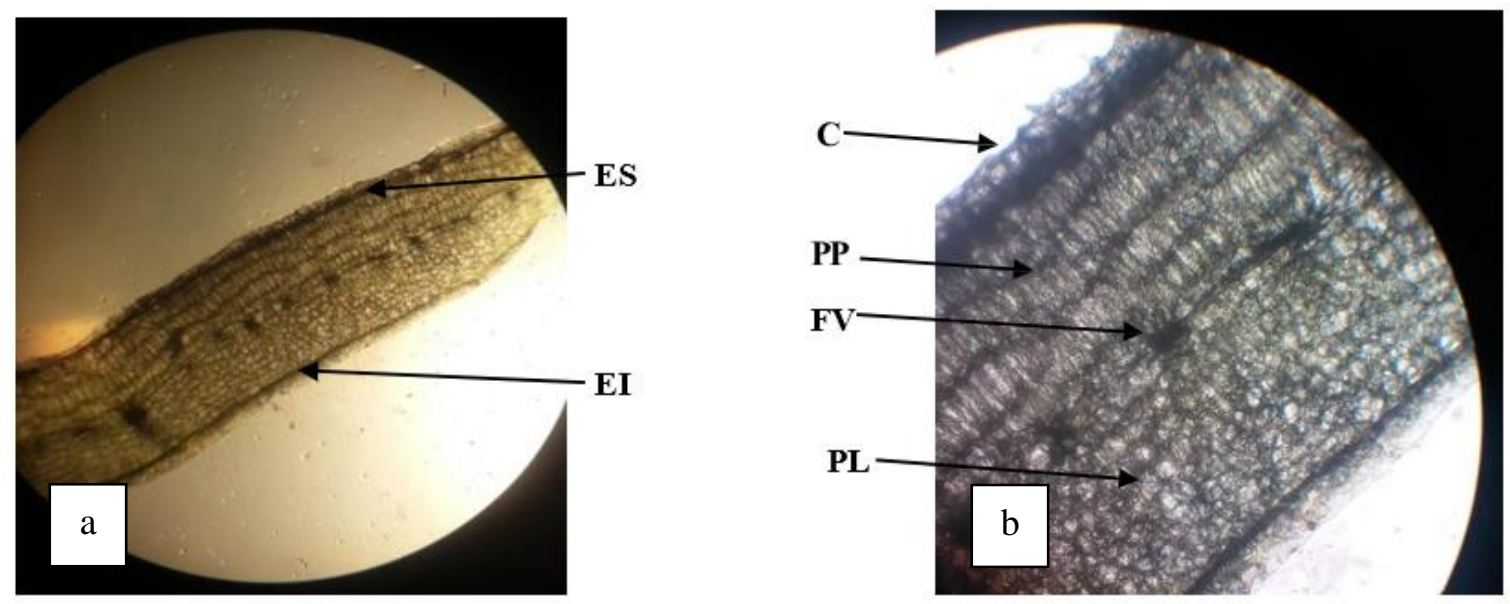

Fonte: SANTOS, 2019.

As imagens das folhas obtidas podem ser usadas para uma ampla discussão sobre suas estruturas, iniciando com aspectos gerais como por exemplo citar que a folha é um apêndice caulinar presente em quase todos os vegetais superiores, salvo exceções, como por exemplo, em algumas espécies da família Cactaceae, cujas folhas são transformadas em espinhos. Em geral são estruturas planas (finas e amplas), de modo que o tecido clorofiliano, responsável pela fotossíntese, fica próximo à superfície (JÚNIOR, 2011, p. 53).

$\mathrm{Na}$ Figura 7, verifica-se ainda a existência da cutícula revestindo a epiderme da folha, estrutura importante para reduzir a perda de água das folhas para a atmosfera.

Substâncias geralmente são depositadas nas estruturas de revestimento dos vegetais, tanto na superfície, quanto no interior das células de revestimento, principalmente das folhas. No interior, os tecidos parenquimáticos podem exibir resistência aos patógenos, mesmo sem apresentar lignificação. A 
resistência nesse caso é atribuída à organização e às características das células (SILVA; ALQUINI; CAVALLET, 2005, p. 184).

Nota-se ainda na Figura 7, a presença dos parênquimas paliçádico e lacunoso (esponjoso). O paliçádico é formado por células alongadas, perpendiculares à epiderme e número variado de camadas. As imagens são concordantes com outros trabalhos, pois o tecido paliçádico, em geral, está voltado para a superfície adaxial da folha (a posição do xilema também indica a superfície adaxial) (SILVA; ALQUINI; CAVALLET, 2005, p. 190). O parênquima esponjoso (lacunoso) é formado por células de formato variado e são normalmente irregulares, sendo localizadas geralmente na superfície abaxial.

Na Figura 8, observa-se um corte transversal do pecíolo da folha do girassol.

Figura 8. Corte transversal do pecíolo da folha do girassol (H. annuus L., Asteraceae) com corante azul de metileno: vista geral com aumento de 10x. (FL: Floema; XI: Xilema; TR: Tricoma).

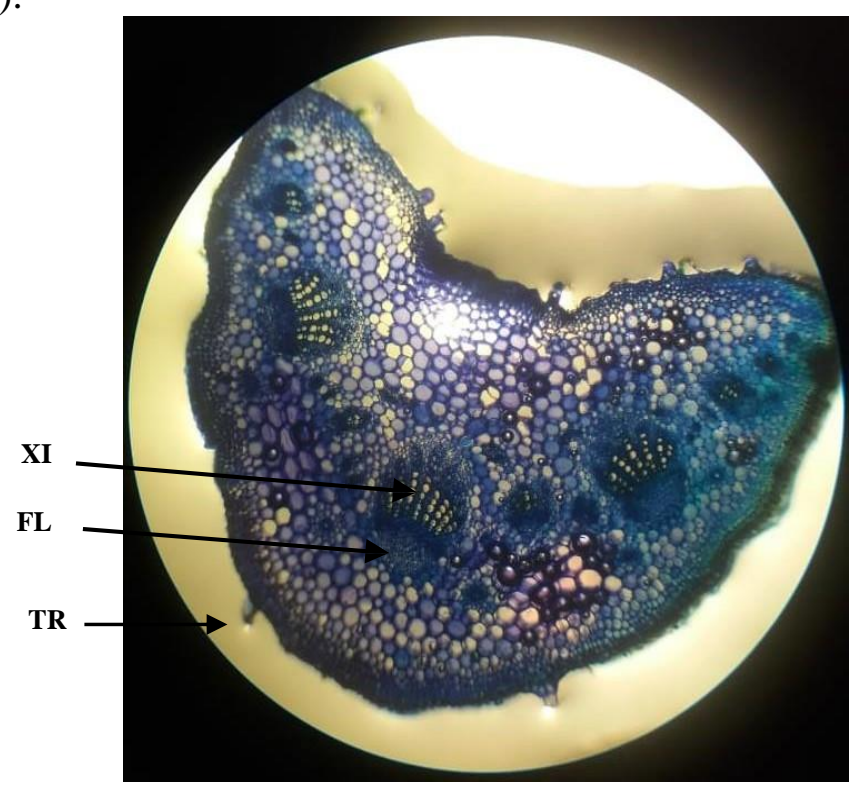

Fonte: SANTOS, 2019

De acordo com Cortez, Silva e Chaves (2016, p. 75), uma folha completa é constituída por lâmina, pecíolo e bainha. O pecíolo é a haste que sustenta a lâmina foliar e a liga ao caule, localizada geralmente na base do limbo, estando ausente nas folhas sésseis e em grande parte das monocotiledôneas.

Segundo Reis, Proença e Sajo (2004, p. 991), o contorno do pecíolo do girassol em seção transversal é côncavo na face adaxial e convexo na face abaxial. O sistema vascular apresentase em forma de arco, acompanhado por feixes acessórios menores e os mesmos são formados por xilema envolvido por floema, conforme observado na Figura 6.

No pecíolo ainda pode-se notar a presença de tricomas emergentes da epiderme superior e inferior. Existem vários tipos de tricomas. Os tricomas ou pêlos das plantas são pequenas protuberâncias da epiderme na superfície da grande maioria das plantas, são capazes de sintetizar e armazenar grande quantidade de metabólitos secundários especializados (glandulares); alguns dos quais podem ter um valor significativo como medicamentos (MATÍAS HERNÁNDEZ, et al, 2017, p. 521). Já os tricomas tectores, que são aqueles presentes na planta em questão, são do tipo tector simples longo multicelular ao longo do pecíolo, nervuras e bordas da lâmina foliar. 


\section{Revista Ambientale \\ Revista da Universidade Estadual de Alagoas/UNEAL \\ e-ISSN 2318-454X, Ano 13, Vol. 13 (1), 2021}

Em trabalho semelhante Júnior (2011, p. 53), constatou que os principais tipos de tricomas encontrados no girassol (Helianthus annuus L., Asteraceae) são dos tipos: curto, uni ou multicelular; longo multicelular e o espiralado multicelular. Os multicelulares apresentamse em maior densidade ao longo das nervuras, principalmente na face abaxial da folha e nas bordas da lâmina foliar seguindo pelo pecíolo podendo ser visto a olho nu.

Quanto a inflorescência, fez-se um corte longitudinal para observação das estruturas internas sem o uso do microscópio (Figura 9). As flores evidenciam o estágio reprodutivo formam-se as inflorescências e flores (EVERT; ESAU, 2013, p. 29). No caso do girassol a inflorescência é do tipo capítulo, composto por flores geralmente sésseis, que se formam no ápice da haste, apresentando alongamento discoide, constituindo um receptáculo onde há a inserção das flores. O receptáculo apresenta brácteas pilosas e ásperas e o diâmetro dos capítulos podem variar conforme a espécie, clima e solo (LENTZ et al. 2001, p. 371).

Figura 9. Imagem a: visão geral da Inflorescência. Imagem b: Anatomia do receptáculo floral do girassol (H. annuus L., Asteraceae). Secção longitudinal. (INF: Inflorescência; FL: Flores; COR: Corola; PET: Pétalas; OV: Ovário; RF: Receptáculo Floral; PED: Pedúnculo; CAL: Cálice; SEP: Sépalas).
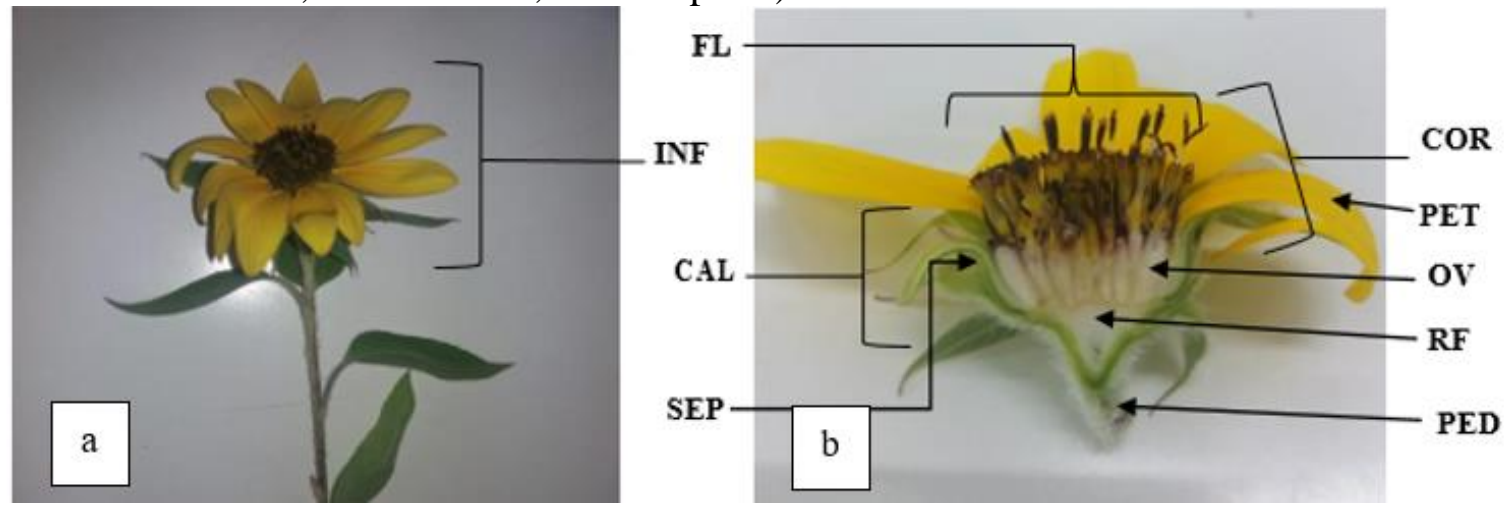

Fonte: SANTOS, 2019.

As flores liguladas da inflorescência do girassol são estéreis, geralmente de cor amarela e situam-se na parte marginal do capítulo com a função de atrair polinizadores. As flores tubulares, que dão origem aos aquênios, são férteis e ocupam todo o espaço central do capítulo, sendo delimitadas pelas flores liguladas (CASTRO; FARIAS, 2005, p. 158). Temos que considerar diante do exposto, mais uma possibilidade de uso do girassol e do método adotado no presente trabalho nas salas de aula, pois tais estruturas são facilmente observadas e, portanto, possível de utilizar no ensino de biologia vegetal.

A flor pode ser considerada um órgão, mas o conceito clássico trata a flor como um conjunto de órgãos homólogos aos ramos. Este conceito implica que as partes florais, algumas das quais são férteis (estames e carpelos) e outras estéreis (sépalas e pétalas), são homologas às folhas (EVERT; ESAU, 2013, p. 29).

Tomando como base o Manual Prático de Morfologia e Anatomia Vegetal de Cortez, Silva e Chaves (2016, p. 29), verificou-se ser eficaz o método utilizado no presente trabalho para a visualização das estruturas anatômicas internas do girassol (H. annuus L., Asteraceae) ao microscópio óptico.

Ademais, levando-se em consideração que atualmente a necessidade de aulas práticas para facilitar o conhecimento, no sentido de melhorar o ensino de Ciências e Biologia nas 
escolas e sendo o professor o mediador de conhecimento, é dever desse, facilitar as formas e meios do aluno aprender o conteúdo com recursos simples e fáceis.

\section{Conclusão}

Conclui-se que utilizar as técnicas usadas no presente trabalho, pode ser uma ferramenta importante para usar no ensino da biologia vegetal. Foi possível observar células e tecidos importantes que são estudados nas aulas de Botânica em Ciências e Biologia tanto no Ensino Fundamental, Médio e Superior que envolvem à anatomia e morfologia vegetal.

O girassol contribui para o ensino botânico devido a planta possuir estruturas anatômicas externa e interna características, bem visíveis a olho nu e ao microscópico óptico, respectivamente.

Como a prática desenvolvida neste trabalho têm-se fácil replicação e um estudo agradável, poderá servir de base para outros trabalhos a ser desenvolvidos com outras plantas, tanto plantas pouco estudadas para tal fim, ou mesmo plantas comumente encontradas em cada região.

\section{Conflito de interesses}

Os autores deste manuscrito não declararam conflitos de interesse. 


\section{Referências}

APPEZZATO-da-GLÓRIA. B; CARMELLO-GUERREIRO, S. M. Anatomia Vegetal. $2^{a}$ edição. Viçosa-MG: Editora da Universidade Federal de Viçosa, 2006. CAVASIN Júnior, C. P. A cultura do girassol. Guaiba: Agropecuária, 69 p, 2001.

CASTRO, C.; FARIAS, J. R. B. Ecofisiolgia do girassol. In: LEITE, R. M. V. B. C. et al. Girassol no Brasil. Londrina: EMBRAPA, p. 163-218, 2005.

CASTRO, T. S; CHALCO, F. P. A importância da Utilização de Aulas Práticas de Fisiologia Vegetal no Processo de Ensino-Aprendizagem de Biologia Aplicada aos Alunos do Ensino Médio. Parintins - AM: Anatomia de Plantas Vasculares, Universidade do Estado do Amazonas - Departamento de Biologia, 2006.

CORTEZ, P. A; SILVA, D. C; CHAVES, A. L. F. Manual prático de morfologia e anatomia vegetal. Ilhéus - BA: Editus, p. 92, 2016.

EVERT, R. F; ESAU, K. Anatomia das plantas de Esau: meristemas, células e tecidos do corpo da planta: sua estrutura, função e desenvolvimento. $1^{\circ}$ Edição, São Paulo - SP: Editora Blucher, 2013.

GROMBONE-GUARATINI, M. T; LEITÃO FILHO, H. F; KAGEYAMA, P. Y. O banco de sementes de uma floresta de galeria no sudeste do Brasil. Brazilian Archives of Biology and Technology. Curitiba - PR, Braz. arco. biol. technol. vol.47 no.5 set. 2004. Disponível em: <http://dx.doi.org/10.1590/S1516-89132004000500015>. Acesso em: 14 Mar. 2021.

INSTITUTO DE BIOLOGIA. Anatomia Vegetal. Uberlândia: Universidade Federal de Uberlândia, 2007. Disponível em: 〈http://www.anatomiavegetal.ib.ufu.br/>. Acesso em: 09 Mar. 2021.

JÚNIOR, L. A. Z. Produção de Girassol ornamental e rosas em vasos por influência da fertilização silicatada. 2011. 77p. Tese - Pós- graduação em Solos e Nutrição de Plantas, Universidade Federal de Viçosa, Minas Gerais, 2011.

KARADOĐAN, T.; AKGÜN, Í. Effect of leaf removal on sunflower yield and yield components and some quality characters. Helia, v.32, p.123-134, 2009.

LENTZ, D.; POHL, M.E.D.; POPE, K.O. WYATT, A.R. Prehistoric sunflower (Helianthus annuus L.) domestication in Mexico. Economic Botany, v.55, p.370-376, 2001.

MATÍAS-HERNÁNDEZ, L; JIANG W; YANG K, TANG K, BRODELIUS PE, PELAZ S. AaMYB1 and its orthologue AtMYB61 affect terpene metabolismo and trichome development in Artmisia annua and Arabidopsis thaliana. The plant jornal, v.90, p.520-534, 2017. 
MELLO, A. C. L. et al. Degradação ruminal da matéria seca de clones de capim-elefante em função da relação folha/colmo. Revista Brasileira de Zootecnia. Viçosa - MG. v.35, n.4, p.1316-1322, 2006.

RIBEIRO, Ana Caroline Moreira. O conteúdo de botânica dos livros didáticos aprovados pelo PNLD 2017. 2019. 99f. Trabalho de Conclusão de Curso (Especialização em ensino em Biociências e Saúde) - Instituto Oswaldo Cruz, Fundação Oswaldo Cruz, Rio de Janeiro, 2019.

RAVEN, P. H.; EVERT, R.F.; EICHHORN, S. E. Biologia vegetal. 8. ed. Rio de Janeiro: Guanabara Koogan, 876p, 2014.

REIS, C; PROENÇA, S. L; SAJO, M. G. Vascularização foliar e anatomia do Pecíolo de Melastomataceae do cerrado do Estado São Paulo, Brasil. Acta bot. bras. v.18(4): 987-999. 2004.

ROSA, L; MOREIRA, I; MONTEIRO, R. Atlas de Anatomia Vegetal. Escola Superior Agrária de Castelo Branco, Portugal, 1985.

ROSOLEM, C. A.; LEITE, V. M. Coffee leaf and stem anatomy under boron deficiency. Revista Brasileira de Ciências do Solo, v. 31, p. 477-483, 2007.

SANTOS DE SOUZA, Girlene. Manual prático de Anatomia Vegetal. Jaguarão/RS: Selbach e autores associados. 66p.: il ISBN: 978-85-917717-1-X CDU 63 - Agricultura, silvicultura, agronomia, zootecnia, 2015.

SILVEIRA, P. S.; PEIXOTO, C. P.; LIMA, V.P.; SILVA, A.P. P.; BLOISI, A. M.; BORGES,V. P. Acúmulo de Massa de Matéria Seca e Desempenho Produtivo de Girassol (Helianthus annuus L.) no Recôncavo Baiano In: Congresso Brasileiro de Agroecologia.(6.: 2009: Curitiba, Paraná). Anais:..- Curitiba. ABA, SOCLA, Governo do Paraná, p.1-5, 2009.

SILVA, L. M; ALQUINI, Y; CAVALLET, V. J. Inter-relações entre a anatomia vegetal e a produção vegetal. Acta bot. bras. 19(1): 183-194p. 2005.

Universidade de São Paulo (USP). Introdução à Biologia Vegetal. São Carlos, 2002.

Universidade Castelo Branco (UCB). Anatomia de Plantas Vasculares. - Rio de Janeiro: UCB, 2006. 